\title{
The Potential For Implementing Zero Waste Practices Based on the Composition of Domestic Waste in The Hospital (Case study: Bandung Adventist Hospital)
}

\author{
Nico Halomoan \\ ${ }^{1}$ Teknik Lingkungan, Institut Teknologi Nasional, Bandung, Indonesia \\ Email: nicohalomoan@itenas.ac.id
}

Received 09 Maret 2021 | Revised 09 Maret 2021 | Accepted 09 Maret 2021

\begin{abstract}
Bandung Adventist Hospital as one of the private hospitals in Bandung City in its activities produces subtantial amount of medical and domestic solid waste. The hospital's domestic solid waste increases with the increase in the number of hospitals. Zero waste initiative can potentially reduce waste to be disposed of in the TPA. The resulting solid waste consists of various compositions that can be used to seek potential for reduction, reuse or recycling. Domestic solid waste generation is calculated using the SNI 19-39641994 approach, samples are taken from kitchens and non-kitchens. The composition of waste is sorted by type and the potential for zero waste seen from the composition. The waste generated by hospital is 0.39 $\mathrm{kg} / \mathrm{bed} /$ day for kitchen, $1.08 \mathrm{~kg} / \mathrm{bed} /$ day for non-kitchen and for all source of waste total $1.47 \mathrm{~kg} / \mathrm{bed} /$ day, lower than the WHO standard $3.2 \mathrm{~kg} / \mathrm{bed} /$ day. The composition of the waste were plastic (17.66\%), papers $(8.25 \%)$, organic waste $(43.99 \%)$, metal $(0,41 \%)$, cardboard $(9,37 \%)$, residue $(17,61 \%)$ and others (2,71\%). Bandung Adventist Hospital has started several efforts to minimize waste. Zero waste application with separated waste can then be processed according to the characteristics of each type of waste. Plastic, paper and cardboard waste can be separated for recycling. Organic waste in the form of food scraps such as rice can be separated for animal feed, digested and composted.
\end{abstract}

Keywords: composition, hospital, domestic waste, minimize, zero-waste,

\begin{abstract}
ABSTRAK
Rumah Sakit Advent Bandung sebagai salah satu rumah sakit swasta di Kota Bandung dalam kegiatannya menghasilkan sejumlahsampah medis dan sampah domestik. Sampah domestik rumah sakit meningkat dengan bertambahnya jumlah rumah sakit. Inisiatif zero waste berpotensi mengurangi limbah yang akan dibuang keTPA. Limbah padat yang dihasilkan terdiri dari berbagai komposisi yang dapat digunakan untuk mencari potensi reduksi, penggunaan kembali atau daur ulang. Penghitungan timbulan limbah padat domestik dilakukan dengan pendekatan SNI 19-3964-1994, sampel diambil dari dapur dan non dapur. Komposisi sampah dipilah menurut jenis dan potensi zero waste dilihat dari komposisinya. Sampah yang dihasilkan rumah sakit adalah 0,39 kg / tempat tidur / hari untuk dapur, 1,08 kg/bed/hari untuk non dapur dan untuk semua sumber sampah sebanyak 1,47 kg /bed/ hari, lebih rendah dari standar WHO 3,2 kg/bed/hari. Komposisi sampah adalah plastik(17,66\%) kertas (8,25\%), sampah organik (43,99\%), logam (0,41\%), karton (9,37\%), residu (17,61\%) dan lain-lain. (2,71\%). Rumah Sakit Advent Bandung telah memulai beberapa upaya untuk minimasi pemborosan. Penerapan zero waste dengan pemisahan sampah selanjutnya dapat diolah sesuai dengan karakteristik masing-masing jenis sampah. Sampah plastik, kertas dan karton dapat dipisahkan untuk didaur ulang. Sampah organik berupa sisa-sisa makanan seperti beras dapat dipisahkan untuk pakan ternak, dicerna dan dibuat kompos.
\end{abstract}

Kata kunci: komposisi, rumah sakit, sampah domestik,minimasi, zero-waste 


\section{INTRODUCTION}

The activities in hospital can generate solid waste. Solid waste from the hospital can be divided into two groups, medical solid waste, which includes hazardous and toxic materials, and domestic waste ( garbage). Hospital waste can be divided as medical waste, infectious waste and domestic waste, if hospital does not collected separately, then all mixed hospital wastes are considered to be infectious waste. All waste originating from activities in the hospital, included in domestic waste type needs to be managed according to Law No.18 of 2008[1]. Indonesia National hospital Accreditation Standards (2012), stated that the hospital must carry out waste management, through sorting and separate the next process.

In general, the growth of hospitals in Indonesia from 2012 to the 2018 has increased by an average of $5.2 \%$, in West Java alone the growth has reached 7\% -8\% per year[2]. National solid waste generation from hospitals in Indonesia was estimated of 376,089 tons/day [3]. Domestic solid waste from health facilities covers $75 \%-90 \%$ of the total solid waste produced, including waste from administration, kitchen, housekeeping and packaging from maintenance activities of hospital facilities. which means that only about $10 \%-25 \%$ of the total solid waste is included in the hazardous waste category[4]. Meanwhile in Indonesia in 2002 domestic waste production was $76.8 \%$ and infectious waste was 23.2\%[5]. Bandung Adventist Hospital is a class B private hospital in the city of Bandung. This hospital serves both outpatient and inpatient activities with a capacity of 254 beds. As a hospital that has achieved Plenary level accreditation which was be given by the Hospital Accreditation Commission (KARS) in 2016, Bandung Adventist Hospital has also managed its waste by dividing the types of waste, but has never conducted a waste composition analysis to see opportunities for reducing waste based on the type of waste that is generated.

Accurate and reliable data on waste composition is essential both for planning and environmental assessment of waste management and improving resource recovery in the community. To develop a waste system and improve technology requires detailed data on the characteristics of the waste material[6]. The findings from the literature review on waste management systems indicate that the traditional waste management system is composed of generation, collection, treatment and, disposal of waste[7].

Zero waste is an alternative to reduce waste that will enter the landfill, this can be done by reusing used materials, recycling and, reducing the use of goods[8]. The 'zero waste product' design ensures that the discarded zero waste product would easily be reused and repaired for extended product lifespan. The zero-waste product is the cradle-to-cradle designed product that does not produce any waste during its life cycle. The zero-waste product eliminates the 'waste phase' from the traditional product lifecycle because, after the end-of-life phase, the zero waste product could either be reused, repaired, or remanufactured to produce a secondary product[7].This concept also known as the 3R (reduce, reuse and recycle) concept. In a study with a questionnaire conducted previously at Narayana Medical College \& Hospital, Nellore, Andhra Pradesh, India, based on the opinion of staff and doctors regarding the eligibility of $3 \mathrm{R}$ application in the hospital. About $77.6 \%$ of doctors think $3 \mathrm{R}$ is possible, even if only partially. Meanwhile, the hospital staff, namely $69.9 \%$ housekeeping and $52.8 \%$, stated that the $3 \mathrm{R}$ concept was possible [9]

With the growth of hospitals, the amount of waste produced increase, zero waste can be an alternative in reducing domestic waste in hospitals. Previous studies used waste composition for analysis of technical aspects of waste management[5], other studies compared the composition of mixed waste, not specifically domestic waste [10], while other studies saw the 3R potential seen from a questionnaire given to hospital staff $[9,11]$. In this study, analysis combines the special composition of domestic waste and tries to analyze the potential for zero waste from the composition of the waste.

Rekayasa Hijau - 92 


\section{METHODOLOGY}

Hospital waste generation rate is fundamental information for evaluating and designing hospital waste disposal systems. Solid waste is divided into groups according to the type of waste and waste groups are weighed again[12]. Primary data in the form of waste measurement results are processed into hospital domestic waste generation value $(\mathrm{Q})$, solid waste density, waste composition percentage, to be then made in the form of a mass balance. The secondary data obtained were used to calculate the potential waste reduction that might be done in the hospital, to determine the recommendations to be given for domestic waste management activities at the Bandung Adventist Hospital.

Measurement of waste generation and composition using SNI 19-3964-1994 regarding methods of taking and measuring samples of generation and composition of urban waste, there is no method that specifically measures waste generation from activities in hospitals. In this measurement, the source of waste will be divided into kitchen and non-kitchen sources, this classification is based on the SOP conducted by the hospital and seeing the general composition based on preliminary observations. Measurements were carried out for 7 days, during which samples were taken from the collected solid waste into the waste storage area. During one of the solid waste collection times, hospital waste was collected 3 times per day. Measured waste for non-kitchen sources is taken from one of the floors, then calculated using the conversion of hospital occupancy data on the floor taken.

Solid waste density can be determined by first measuring the mass and volume of waste from the samples that have been taken. The sample will be put in a standard container to measure the volume and mass of the waste sample. Based on the measured volume and weight of waste, the daily amount will be calculated by multiplying the number of collections in one day. The amount of waste is divided by the number of beds occupied. This occupancy rate can be determined by first looking for Bed Occupancy Ratio (BOR) data. Equation 1 described steps to calculate weight per bed, to measure the volume in the same steps but the sample size is liters.

Amount of Waste per bed (qns) $(\mathrm{kg} / \mathrm{bed})=\frac{\text { Weight of sample }(\mathrm{kg}) \times \text { Ritation }}{\text { total bed } x \text { BOR }}$

The calculation for the total waste generation is calculated using the equation:

with:

$$
Q n s=q n s \times P
$$

Qns $=$ total waste generation $(1 /$ day $)$ or $(\mathrm{kg} /$ day $)$

qns $=$ unit of waste generation $(1 / \mathrm{bed} / \mathrm{day})$ or $(\mathrm{kg} / \mathrm{bed} / \mathrm{day})$

$\mathrm{P}=$ total hospital beds (bed)

The calculation to get the density of solid waste uses the equation:

with:

$$
\rho=\frac{B s}{V s}
$$

$\rho=$ waste density $\left(\mathrm{kg} / \mathrm{m}^{3}\right)$

Bs $=$ weight of waste $(\mathrm{kg})$

Vs $=$ volume of waste $\left(\mathrm{m}^{3}\right)$

The composition of waste is a physical component of waste, in this research it will consist of plastics, paper, food scraps, metals, and others. Waste that will be sorted based on composition is domestic waste that has previously been separated from medical and hazardous waste. The composition of domestic waste generated in the hospital is calculated using the equation:

composition $=\frac{\text { Weight per type of waste }(\mathrm{kg})}{\text { Total weight of all sample }(\mathrm{kg})} \times 100 \%$ 
The principle of zero waste is a waste management concept based on recycling activities (Recycle). To determine the potential domestic solid waste that can be zero waste, the potential waste generation is first calculated at peak conditions where it is assumed that all the beds are fully occupied. The zero waste potential from the waste generated can be seen by examining the potential for reduction and recycling of types of waste whose composition and characteristics have been measured. The flowchart showed methodology of this research can be seen in the figure 1.

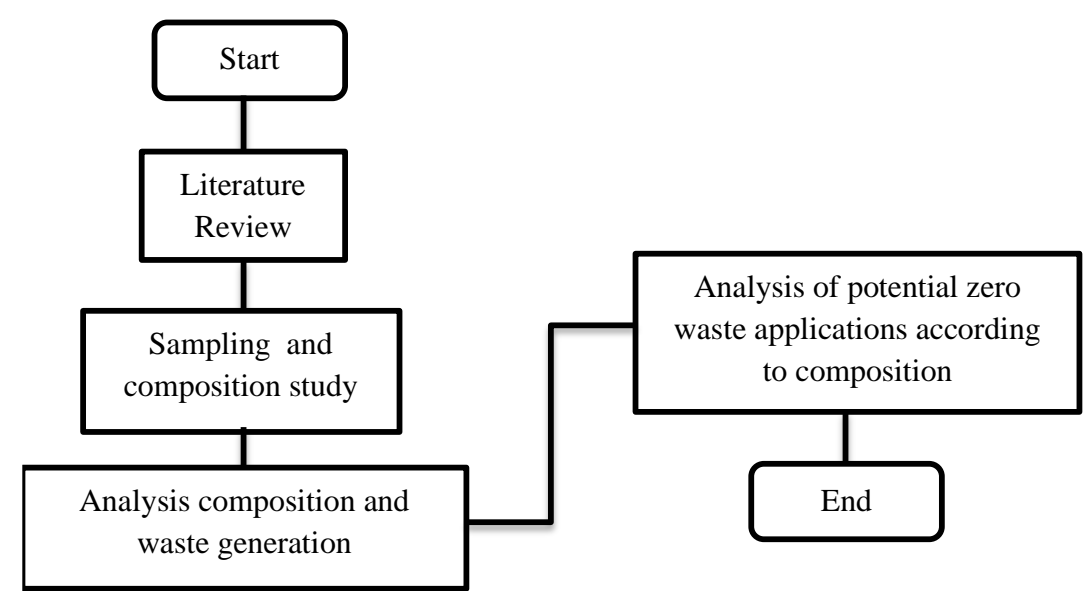

Figure 1. Flowchart diagram methodology

\section{RESULT AND DISCUSSION}

The potential for zero waste application can be seen by first looking for the density of waste and composition of the waste as measured by SNI 19-3964-1994. Bandung Adventist Hospital has 254 beds, and when the survey was taking place the bed occupancy ratio (BOR) was $55.47 \%$, so the number of beds used as the basis for determining the rate of waste generation was 141 beds. The Adventist Hospital in its waste management has separated solid waste collection between domestic solid waste and medical solid waste including Hazardous Material waste that requires special management. Adventist Hospital has two types of domestic temporary waste storage (TPS), namely TPS organic and inorganic. The organic domestic TPS collects waste from the kitchen and the hospital grounds, while the inorganic domestic TPS collects waste from other units in the hospital.

Sampling was carried out for 7 days, of the 8 days that should be done, this was done because there was one day when the hospital did not fully operate the hospital's activities, namely Saturday. Waste that comes from the kitchen is waste from cooking activities for patient food and waste from patient food that is collected again by the staff after each meal. Meanwhile, non-kitchen sources consist of domestic waste from patient rooms, offices, waiting rooms, lobbies and employee rooms. The rate of waste generation and composition in across the unit will be different. The difference is due to the characteristics of each unit. The units have different specific activities. As found in this study, the composition and rate of waste generation in the kitchen is different from that produced in patient rooms and offices.

Table 1 shows the results of the calculation of the waste generation rate (Table 1), for kitchen sources $1.33 \mathrm{~L} / \mathrm{bed} / \mathrm{day}$ or $0.39 \mathrm{~kg} / \mathrm{bed} / \mathrm{day}$, another research got rate of waste generation from four hospital kitchen waste in Sivas City, Turkey is $1.25-2.6 \mathrm{~kg} / \mathrm{bed} /$ day or total $317.9 \mathrm{~kg} / \mathrm{day}[12]$. From non-kitchen waste weight of waste generation is $1.08 \mathrm{~kg} / \mathrm{bed} / \mathrm{day}$ and for all source of waste total $1.47 \mathrm{~kg} / \mathrm{bed} / \mathrm{day}$. 
Then compared to the results of calculations of waste generation from various hospitals researched by Ali et al. (2017) the amount of waste generated by various hospital samples based on secondary data studies, domestic waste generation at Advent Bandung hospitals indicated a higher than some hospitals. in China, Turkey and India [10].

Table 1. Waste Generation Rate

\begin{tabular}{cccc}
\hline $\begin{array}{c}\text { Source of } \\
\text { Waste }\end{array}$ & $\begin{array}{c}\text { Volume } \\
(\mathbf{L} / \mathbf{b e d} / \mathbf{d a} \\
\mathbf{y})\end{array}$ & $\begin{array}{c}\text { Weight } \\
(\mathbf{k g} / \mathbf{b e d} / \mathbf{d a} \\
\mathbf{y})\end{array}$ & $\begin{array}{c}\text { Density } \\
(\mathbf{k g} / \mathbf{L})\end{array}$ \\
\hline AKitchen & 1.33 & 0.39 & 0.29 \\
\hline Non-Kitchen & 10.83 & 1.08 & 0.10 \\
\hline Total & $\mathbf{1 2 . 1 6}$ & $\mathbf{1 . 4 7}$ & $\mathbf{0 . 1 2}$ \\
\hline
\end{tabular}

Table 2. The Average Percentation of Physical Composition of Solid Waste Generation per Day

\begin{tabular}{cccc}
\hline $\begin{array}{c}\text { Kind of } \\
\text { Waste }\end{array}$ & $\begin{array}{c}\text { Percentatege } \\
\text { from Kitchen }\end{array}$ & $\begin{array}{c}\text { Percentage } \\
\text { Nonitchen (kg) }\end{array}$ & $\begin{array}{c}\text { Average } \\
\text { Percentage }\end{array}$ \\
\hline Plastic & $11,03 \%$ & $20,02 \%$ & $17.66 \%$ \\
\hline Paper & $1,55 \%$ & $10,64 \%$ & $8.25 \%$ \\
\hline Organic Waste & $0,00 \%$ & $3,42 \%$ & $43.99 \%$ \\
\hline Metal & $72,06 \%$ & $30,55 \%$ & $0.41 \%$ \\
\hline Cardboard & $0,00 \%$ & $0,55 \%$ & $9.37 \%$ \\
\hline Residue & $4,82 \%$ & $11,00 \%$ & $17.61 \%$ \\
\hline Others & $4,71 \%$ & $22,22 \%$ & $2.71 \%$ \\
\hline Totals & $100 \%$ & $100 \%$ & $100.00 \%$ \\
\hline
\end{tabular}

It is seen also occur when check the composition and generation of all types of waste in a hospital, the type of waste will depend on the type of diagnosis on a patient in each room / activity [1], The physical composition of waste in this studied were plastic $(17.66 \%)$, papers $(8.25 \%)$, organic waste $(43.99 \%)$, metal $(0,41 \%)$, cardboard $(9,37 \%)$, residue $(17,61 \%)$ and others $(2,71 \%)$, organic waste is the largest type of waste (Table 2 and Figure 1). Comparing to those studied in Amol City, Iran there is plastic $(30,2 \%)$ was the largest and only 17,8\% organic waste[13] . According studied in Sivas, Turkey organic waste (17.1\%) and the largest is plastic (41\%)[12]in Kuwait, food waste (26\%) and the largest are 
paper/cardboard (31\%)[14]. There studied for all kind waste in hospital, medical waste domination with plastic and hazardous waste.

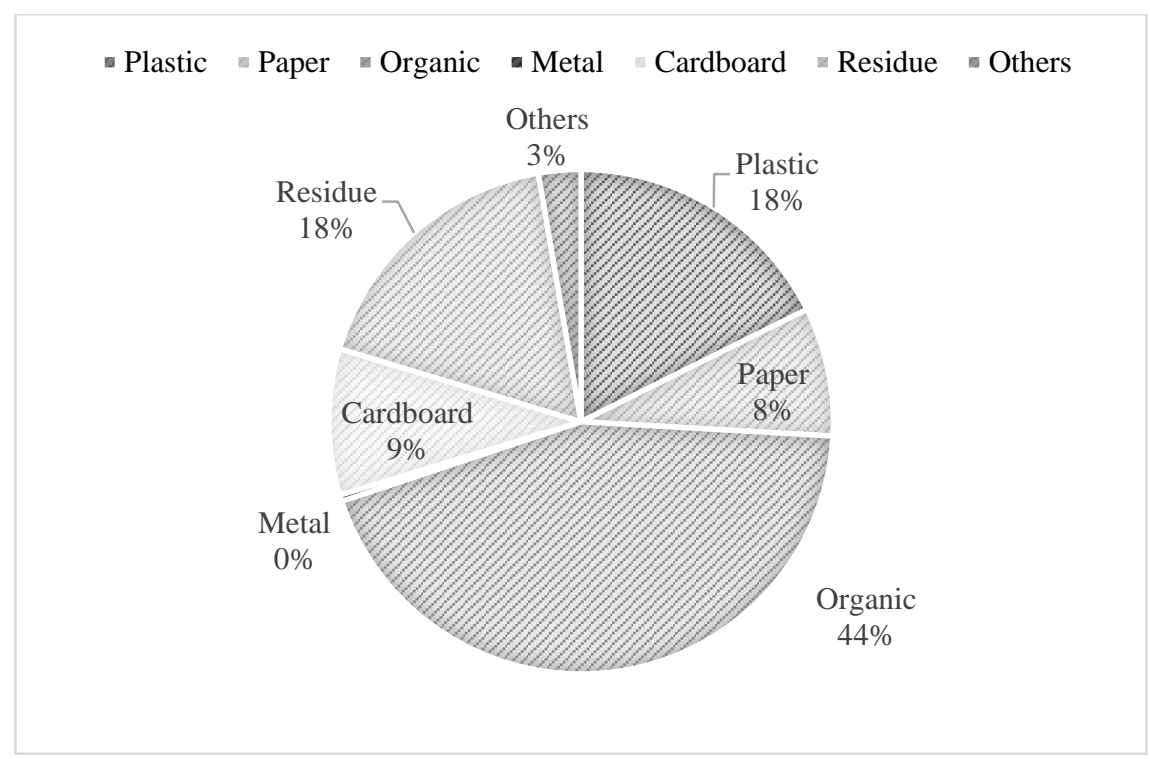

Figure 2. Physical Composition of Hospital Domestic Waste

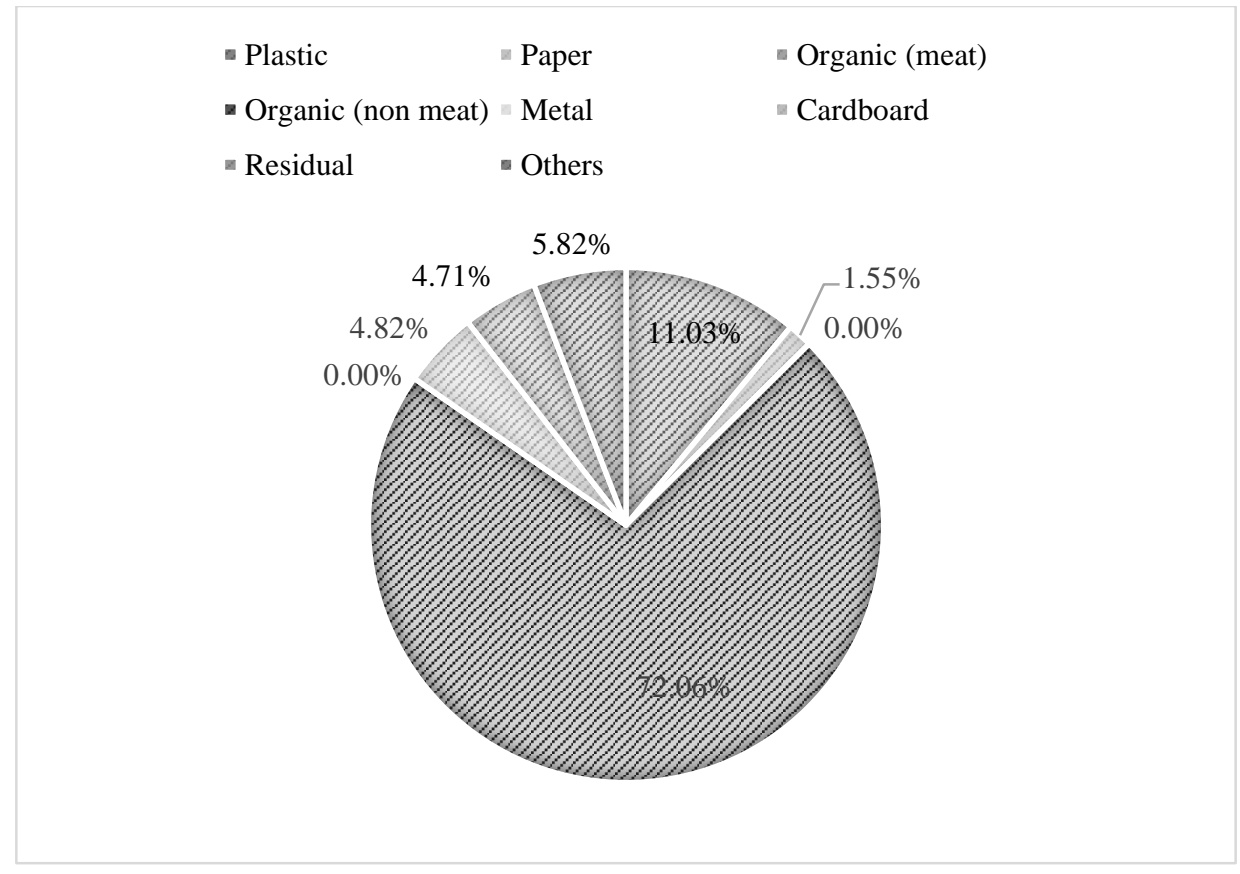

Figure 3. Average Domestic Waste Composition Bandung Adventist Hospital from the Kitchen

Analysis of the composition of the waste comes from a sampling source. waste originating from the kitchen (Figure 34, the largest composition is vegetation organic waste which includes vegetable, fruit and food scraps which reaches $72.06 \%$, other types of waste from the kitchen come from packaging used for activities in the kitchen. Meanwhile, the largest non-kitchen waste is organic vegetation (Figure 4 ), which is followed by residual waste and plastic waste. 


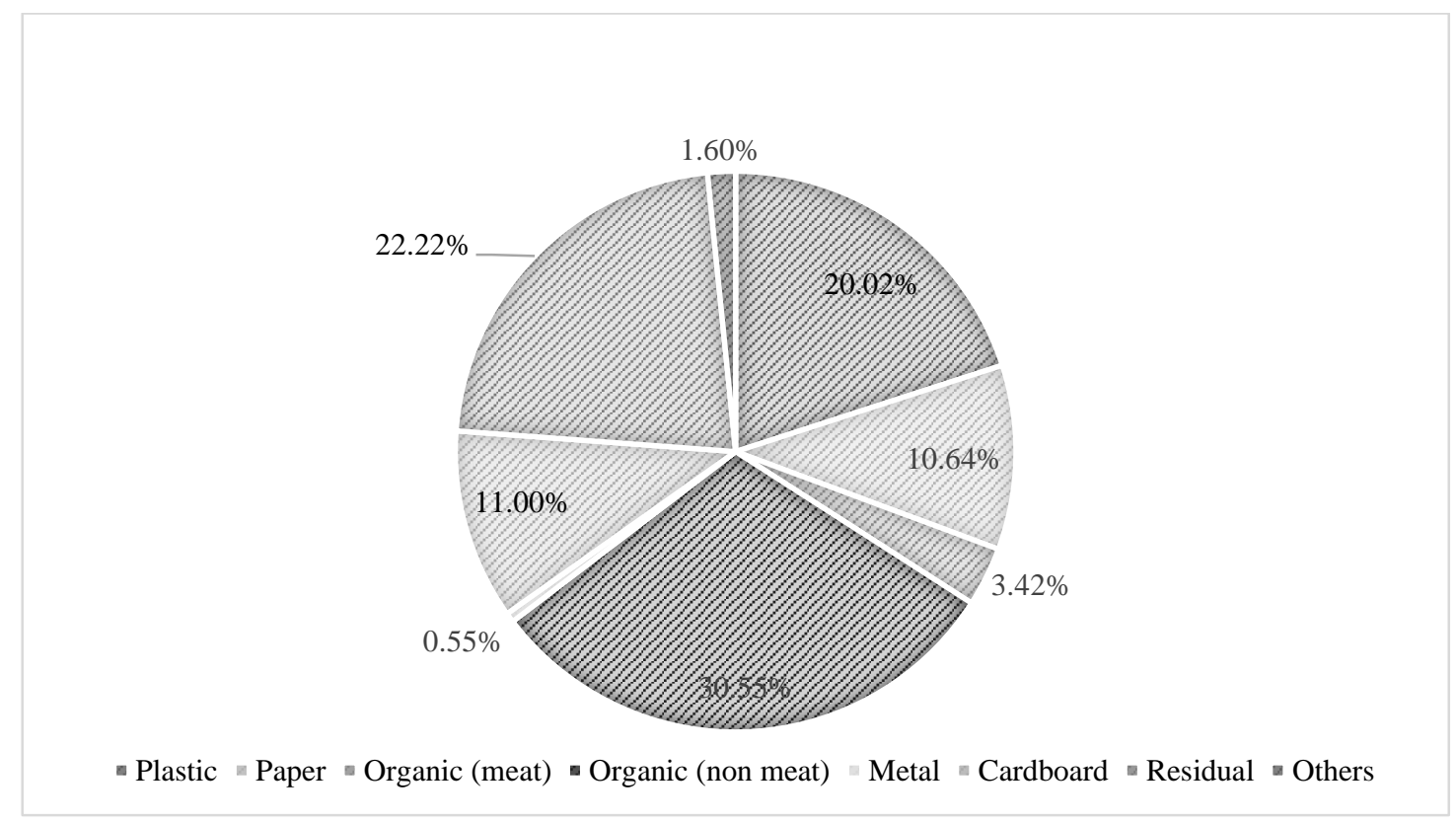

Figure 4. Average Domestic Waste Composition Bandung Adventist Hospital from the Non-Kitchen

Table 3. The Potential Composition of Maximum Solid Waste Generation per Day

\begin{tabular}{cccc}
\hline $\begin{array}{c}\text { Kind of } \\
\text { Waste }\end{array}$ & $\begin{array}{c}\text { Kitchen } \\
(\mathbf{k g})\end{array}$ & $\begin{array}{c}\text { Non } \\
\text { Kitchen }(\mathbf{k g})\end{array}$ & $\begin{array}{c}\text { Total } \\
(\mathbf{k g})\end{array}$ \\
\hline Plastic & 10.85 & 55.19 & 66.04 \\
\hline Paper & 1.52 & 29.34 & 30.86 \\
\hline Organic Waste & 70.87 & 93.66 & 164.52 \\
\hline Metal & 0.00 & 1.52 & 1.52 \\
\hline Cardboard & 4.74 & 30.31 & 35.05 \\
\hline Residue & 4.63 & 61.25 & 65.88 \\
\hline Others & 5.73 & 4.41 & 10.14 \\
\hline Totals & 98.34 & 275.68 & 374.02 \\
\hline
\end{tabular}

In terms of waste management, Bandung Adventist Hospital has started implementing several waste minimization efforts before the waste is disposed off and collected to the garbage collection. Waste minimization efforts that have been carried out in the office area are indicated by the existence of policies for employees, including limiting the use of tissue paper in the office, reusing paper, reusing food and beverage containers that can be reused, and there is a policy to separate food waste. The success or failure of a zero-waste concept apart from being supported by technical aspects of sorting and reducing waste, with the existing potential needs to be supported by the personal rules and culture of everyone connected with the hospital such as employees, patients and guests.

The zero waste management system requires an effective implementation strategy along with a reliable performance measurement mechanism[7]. It is possible to avoid and prevent waste creation of unwanted and excessive waste through sustainable consumption. In addition to the sustainable consumption, a systematic transformation of existing inefficient manufacturing systems is also required for eliminating waste creation [15]. Another consideration in selecting and designing a zero-waste based to waste management system for future capacity. It is a known fact that the amount of waste will increase along with the increase in the number of patients and the advancement of health technology. Separate collection of hospital waste is not only domestic and medical waste, but includes plastic and paper waste. 
Will reduce investment and final processing operational costs. Based on the type of composition that exists in domestic waste at Adventist Hospital, several efforts to reduce waste that can be done by the hospital can be recommended.

The zero waste potential will be divided based on the calculated waste composition. The composition of inorganic waste found in domestic waste at Adventist Hospital includes plastic, paper, metal, cardboard, residual waste, and other waste that are not included in the categories that have been mentioned. Cardboard waste that enters the container facility is cardboard waste for medical equipment packaging (masks, gloves), food packaging and medicine packaging.

Table 4. Potential Zero Waste by Composition

\begin{tabular}{cccc}
\hline Kind of Waste & Reduce & Reuse & Recyle \\
\hline Plastic & $\mathrm{v}$ & & $\mathrm{v}$ \\
\hline Paper & $\mathrm{v}$ & $\mathrm{v}$ & $\mathrm{v}$ \\
\hline Organic waste & $\mathrm{v}$ & & $\mathrm{v}$ \\
\hline Cardboard & $\mathrm{v}$ & $\mathrm{v}$ & $\mathrm{v}$ \\
\hline Residual & $\mathrm{v}$ & & \\
\hline Others & $\mathrm{v}$ & & \\
\hline
\end{tabular}

The composition of the waste is analyzed according to the potential for the $3 \mathrm{R}$ (reduce, reuse and recycle) to be carried out. Table 4 shows the results of the analysis, where all types of waste have the potential to be reduced. Reduction of waste will provide benefits for the perpetrators, because the reduction or replacement of materials used can reduce costs incurred for both the provision of goods and waste management, and reduce the risk of unused waste becoming residual and other uncategorized waste.

One of the waste that has the potential to be reduced is organic waste from kitchen scraps as well as from food scraps thrown away by visitors / employees. Actions that can be taken are to try to change portion sizes, make food choice options, or help a nutritionist for the type and portion of food that is suitable for the patient, and changes to the food delivery system. Increasing the ability of patients to choose their diet with a selective menu and a wider choice also appears to be successful in reducing waste generation. Likewise, mass food service (or buffet) systems, in which patients choose their food at the time of service, have consistently been shown to reduce leftover food waste, although for hospital activities this is somewhat difficult to implement [16].

Hospital based on waste composition is ranked high to very high priority and is important by looking at the various waste compositions in the waste management system to maximize recovery efforts from existing resources. Segregation starting from the source can facilitate domestic waste processing so it is advisable to implement a separate waste disposal system by providing separate bins based on the type of waste. The separated waste can then be processed according to the characteristics of each type of waste. Plastic, paper and cardboard waste can be separated for recycling, either independently by the hospital or in collaboration with third parties for processing. Organic waste in the form of food scraps such as rice can be separated to be used as animal feed.

In the concept of zero waste, the presence of waste generated can be utilized, such as food waste that can become compost which can then be used as organic fertilizer with a more balanced nutrient content with chemical fertilizers. Food waste has a high potential for methane gas production, and is quickly broken down so that it can be used as raw material for the digestion process[17]. For inorganic waste 
generated from non-kitchen activities, goods can be procured that are more environmentally friendly, or as much as possible are used for the long term so that they are environmentally friendly[4]. One of the advantages of zero waste is a reduction in procurement costs and will provide added value for the hospital.

\section{CONCLUSION}

An understanding of the composition of hospital waste is fundamental in determining the types of waste that have the potential to be reduced and recycled as an application of the zero-waste concept. The waste generated by hospital is $0.39 \mathrm{~kg} / \mathrm{bed} /$ day for kitchen, $1.08 \mathrm{~kg} / \mathrm{bed} /$ day for non-kitchen and for all source of waste total $1.47 \mathrm{~kg} / \mathrm{bed} /$ day. The composition of the waste were plastic $(17.66 \%)$, papers $(8.25 \%)$, organic waste $(43.99 \%)$, metal $(0,41 \%)$, cardboard $(9,37 \%)$, residue $(17,61 \%)$ and others $(2,71 \%)$. With this composition, it has a specific way to be managed by reducing waste generation and recycling of the waste composition. The resulting organic waste has a lot of potential for further processing such as composting, digester, and use as animal feed. Bandung Adventist Hospital with a management commitment to maintain and improve the quality of the hospital, the various potentials of waste generated can be pursued to develop a zero-waste concept in waste management.

\section{ACKNOWLEDGEMENTS}

The study was conducted at the Bandung Adventist Hospital and was funded by the ITENAS Young Lecturer Research Award 2020 which was organized by LPPM ITENAS.

\section{REFERENCES}

[1] Undang-Undang No. 18 Tahun 2008 tentang Pengelolaan Sampah, R. Indonesia, 2008.

[2] L. Trisnantoro and E. Listyani. (2018, April). Jumlah RS di Indonesia Pertumbuhan Rumah Sakit Publik. Available: https://www.persi.or.id/analis-data/441-jumlah-rs-di-indonesiapertumbuhan-rs-publik

[3] A. Astuti and S. Purnama, "Kajian Pengelolaan Limbah di Rumah Sakit Umum Provinsi Nusa Tenggara Barat (NTB)," Community Health, vol. 2, no. 1, pp. 12-20, 2014.

[4] Y. Chartier, Safe management of wastes from health-care activities. World Health Organization, 2014.

[5] A. R. Pradipta, "Analisis Aspek Teknis Operasional Pengelolaan Sampah di RSUD Ade Moehammad Djoen Kota Sintang," Jurnal Teknologi Lingkungan Lahan Basah, vol. 3, no. 1, 2015.

[6] M. E. Edjabou, C. Petersen, C. Scheutz, and T. F. Astrup, "Food waste from Danish households: Generation and composition," Waste Manag, vol. 52, pp. 256-68, Jun 2016.

[7] A. U. Zaman, "Identification of key assessment indicators of the zero waste management systems," Ecological Indicators, vol. 36, pp. 682-693, 2014.

[8] Q. Song, J. Li, and X. Zeng, "Minimizing the increasing solid waste through zero waste strategy," Journal of Cleaner Production, vol. 104, pp. 199-210, 2015.

[9] R. M. Desu, S. K. Saginela, and G. Ram, "Facilitating Sustainable Waste Management Strategies Within the Hospital-An Explorative Study," in Solid Waste Policies and Strategies: Issues, Challenges and Case Studies: Springer, 2020, pp. 57-72.

[10] M. Ali, W. Wang, N. Chaudhry, and Y. Geng, "Hospital waste management in developing countries: A mini review," Waste Management \& Research, vol. 35, no. 6, pp. 581-592, 2017.

[11] B. Edra, B. Magalhães, M. Silva, and M. do Céu Costa, "Health Professionals Knowledge of Hospital Waste Sorting and Storage." 
[12] S. Altin, A. Altin, B. Elevli, and O. Cerit, "Determination of hospital waste composition and disposal methods: a case study," Polish Journal of Environmental Studies, vol. 12, no. 2, pp. 251-255, 2003.

[13] O. L. Rabeie et al., "Determination of Hospital Waste Composition and Management in Amol City, Iran," (in en), Health Scope, Research Article vol. 1, no. 3, pp. 127-31, 2012.

[14] J. M. Alhumoud and H. M. Alhumoud, "An analysis of trends related to hospital solid wastes management in Kuwait," Management of Environmental Quality: An International Journal, 2007.

[15] A. U. Zaman, "A comprehensive review of the development of zero waste management: lessons learned and guidelines," Journal of Cleaner Production, vol. 91, pp. 12-25, 2015.

[16] P. Williams and K. Walton, "Plate waste in hospitals and strategies for change," e-SPEN, the European e-Journal of Clinical Nutrition and Metabolism, vol. 6, no. 6, pp. e235-e241, 2011.

[17] B. Dearman and R. Bentham, "Anaerobic digestion of food waste: Comparing leachate exchange rates in sequential batch systems digesting food waste and biosolids," Waste management, vol. 27, no. 12, pp. 1792-1799, 2007. 